\title{
Laboratory management of Crimean-Congo haemorrhagic fever virus infections: perspectives from two European networks
}

Barbara Bartolini ${ }^{1}$, Cesare EM Gruber ${ }^{1}$, Marion Koopmans ${ }^{2}$, Tatjana Avšič ${ }^{3}$, Sylvia Bino ${ }^{4}$, Iva Christova 5 , Roland Grunow ${ }^{6}$, Roger Hewson ${ }^{7}$, Gulay Korukluoglu ${ }^{8}$, Cinthia Menel Lemos ${ }^{9}$, Ali Mirazimi ${ }^{10,11,12}$, Anna Papa ${ }^{13}$, Maria Paz Sanchez-Seco ${ }^{14}$, Aisha V. Sauer ${ }^{15}$, Hervè Zeller ${ }^{16}$, Carla Nisii ${ }^{1}$, Maria Rosaria Capobianchi ${ }^{1}$, Giuseppe Ippolito ${ }^{1}$, Chantal B. Reusken ${ }^{2,17,18}$, Antonino Di Caro ${ }^{1,18}$

1. 'L. Spallanzani' National Institute for Infectious Diseases IRCCS (INMI), WHO Collaborating Center for Clinical Care, Diagnosis, Response and Training on Highly Infectious Diseases, Rome, Italy

2. Erasmus MC, Department of Viroscience, WHO Collaborating Centre for Arbovirus and Viral Hemorrhagic Fever Reference and Research, Rotterdam, The Netherlands

3. Institute of Microbiology and Immunology, Faculty of Medicine, Ljubljana, Slovenia

4. Control of Infectious Diseases Department Institute of Public Health, Tirana, Albania

5. National Center of Infectious and Parasitic Diseases, Sofia, Bulgaria

6. Robert Koch Institute, Berlin, Germany

7. Public Health England, National Infection Service WHO Collaborating Centre for Virus Reference and Research (Special Pathogens), Porton Down, Salisbury, United Kingdom

8. Public Health General Directorate of Turkey, AnkaraCity, Turkey

9. Consumers, Health, Agriculture and Food Executive Agency (CHAFEA), Luxembourg, Luxembourg

10. Public Health agency of Sweden, Solna, Sweden

11. National Veterinary Institute, Uppsala, Sweden

12. Department of Laboratory Medicine, Clinical Microbiology, Karolinska Institute and Karolinska University Hospital, Solna, Sweden

13. Department of Microbiology, Medical School, Aristotle University of Thessaloniki, Thessaloniki, Greece

14. National Centre of Microbiology, Institute of Health Carlos III, Madrid, Spain

15. European Commission, Directorate General for Health and Food Safety, Unit for Crisis Management and Preparedness in Health, Luxembourg, Luxembourg

16. European Center for Disease Prevention and Control, Office of the Chief Scientist, Stockholm, Sweden

17. Centre for Infectious Disease Control, National Institute for Public Health and the Environment (RIVM), Bilthoven, the Netherlands

18. Authors contributed equally to the work and share last authorship

Correspondence: Antonino Di Caro (antonino.dicaro@inmi.it)

Citation style for this article:

Bartolini Barbara, Gruber Cesare EM, Koopmans Marion, Avšič Tatjana, Bino Sylvia, Christova Iva, Grunow Roland, Hewson Roger, Korukluoglu Gulay, Lemos Cinthia Menel, Mirazimi Ali, Papa Anna, Sanchez-Seco Maria Paz, Sauer Aisha V., Zeller Hervè, Nisii Carla, Capobianchi Maria Rosaria, Ippolito Giuseppe, Reusken Chantal B., Di Caro Antonino. Laboratory management of Crimean-Congo haemorrhagic fever virus infections: perspectives from two European networks. Euro Surveill. 2019;24(5): pii=1800093. https://doi.org/10.2807/1560-7917.ES.2019.24-5.1800093

Background: Crimean-Congo haemorrhagic fever virus (CCHFV) is considered an emerging infectious disease threat in the European Union. Since 2000, the incidence and geographic range of confirmed CCHF cases have markedly increased, following changes in the distribution of its main vector, Hyalomma ticks. Aims: To review scientific literature and collect experts' opinion to analyse relevant aspects of the laboratory management of human CCHF cases and any exposed contacts, as well as identify areas for advancement of international collaborative preparedness and laboratory response plans. Methods: We conducted a literature review on CCHF molecular diagnostics through an online search. Further, we obtained expert opinions on the key laboratory aspects of CCHF diagnosis. Consulted experts were members of two European projects, EMERGE (Efficient response to highly dangerous and emerging pathogens at EU level) and EVDLabNet (Emerging Viral Diseases-Expert Laboratory Network).Results: Consensus was reached on relevant and controversial aspects of CCHF disease with implications for laboratory management of human CCHF cases, including biosafety, diagnostic algorithm and advice to improve lab capabilities. Knowledge on the diffusion of CCHF can be obtained by promoting syndromic approach to infectious diseases diagnosis and by including CCHFV infection in the diagnostic algorithm of severe fevers of unknown origin. Conclusion: No effective vaccine and/or therapeutics are available at present so outbreak response relies on rapid identification and appropriate infection control measures. Frontline hospitals and reference laboratories have a crucial role in the response to a CCHF outbreak, which should integrate laboratory, clinical and public health responses.

\section{Introduction}

Crimean-Congo haemorrhagic fever virus (CCHFV) is a tick-borne pathogen that causes a frequently lethal disease in humans and is considered to be a major 


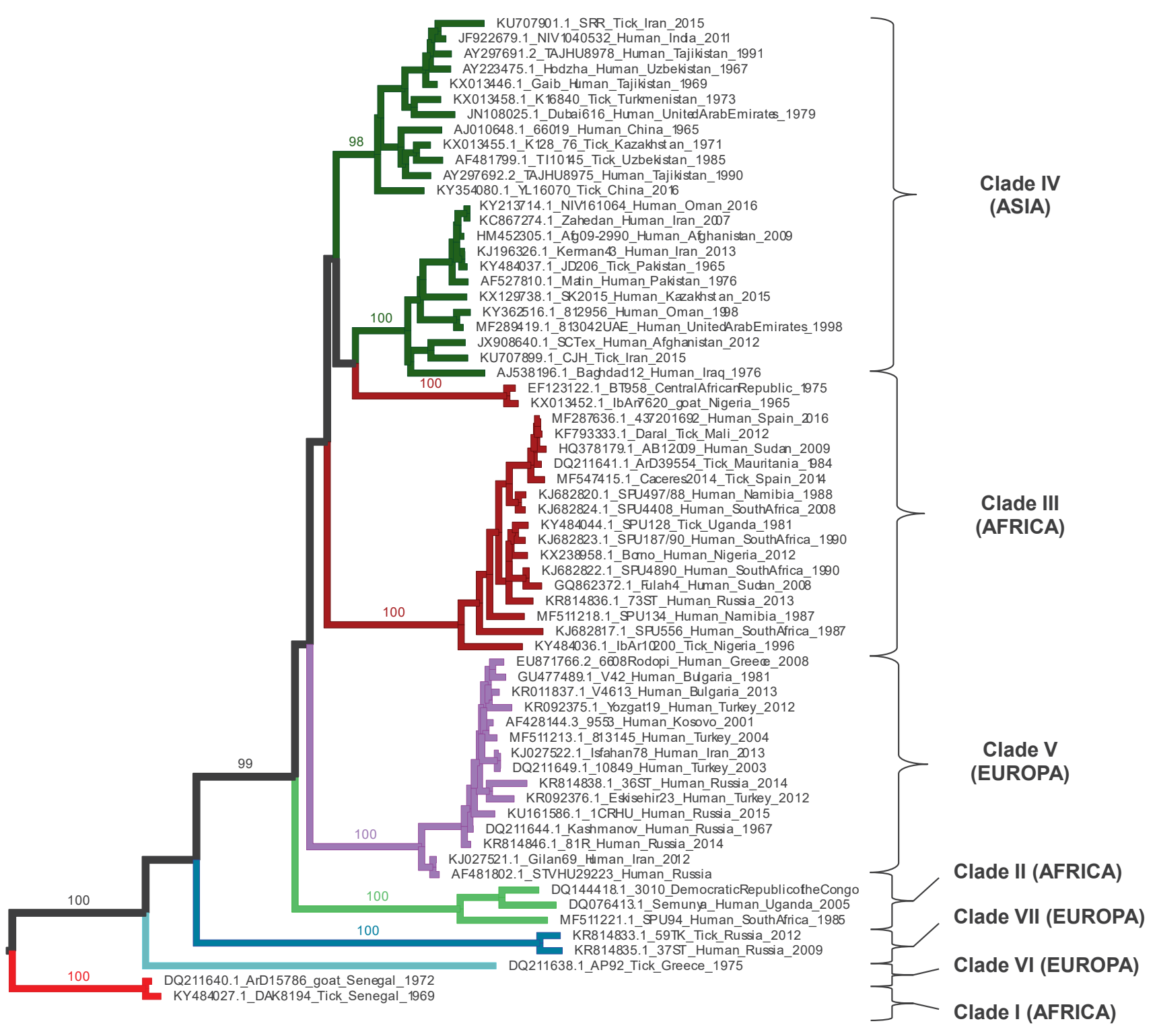

Crimean-Congo haemorrhagic fever virus strains with complete $S$ segment available as at 5 December 2017, were collected from GenBank database and clustered at $100 \%$ with CD-HIT V4.6. Sequences were aligned with MAFFT v7.123b. Phylogenetic analysis were performed using RAxML v8.2.10 with GTRGAMMA model and 1,000 bootstrap inferences. For graphical exemplification, only representative sequences in each clade for each country were selected and reported in the phylogenetic tree.

Branches owing to different clades are presented in the following colours: Africa: clade I (red), clade II (light green) and clade III (brown); Asia: clade IV (dark green); Europe: clade V (purple), clade VI (light blue) and clade VII (blue). For each strain we reported GenBank ID, isolate ID, host, country and collection date, if present. Bootstrap values are shown for each clade.

emerging infectious disease threat spreading to and within Europe [1-3].
The severity of the disease, the presence of domestic and wild animal reservoirs and/or vectors, a large population of susceptible humans, limited diagnostic capacities and resources for epidemiological/ 


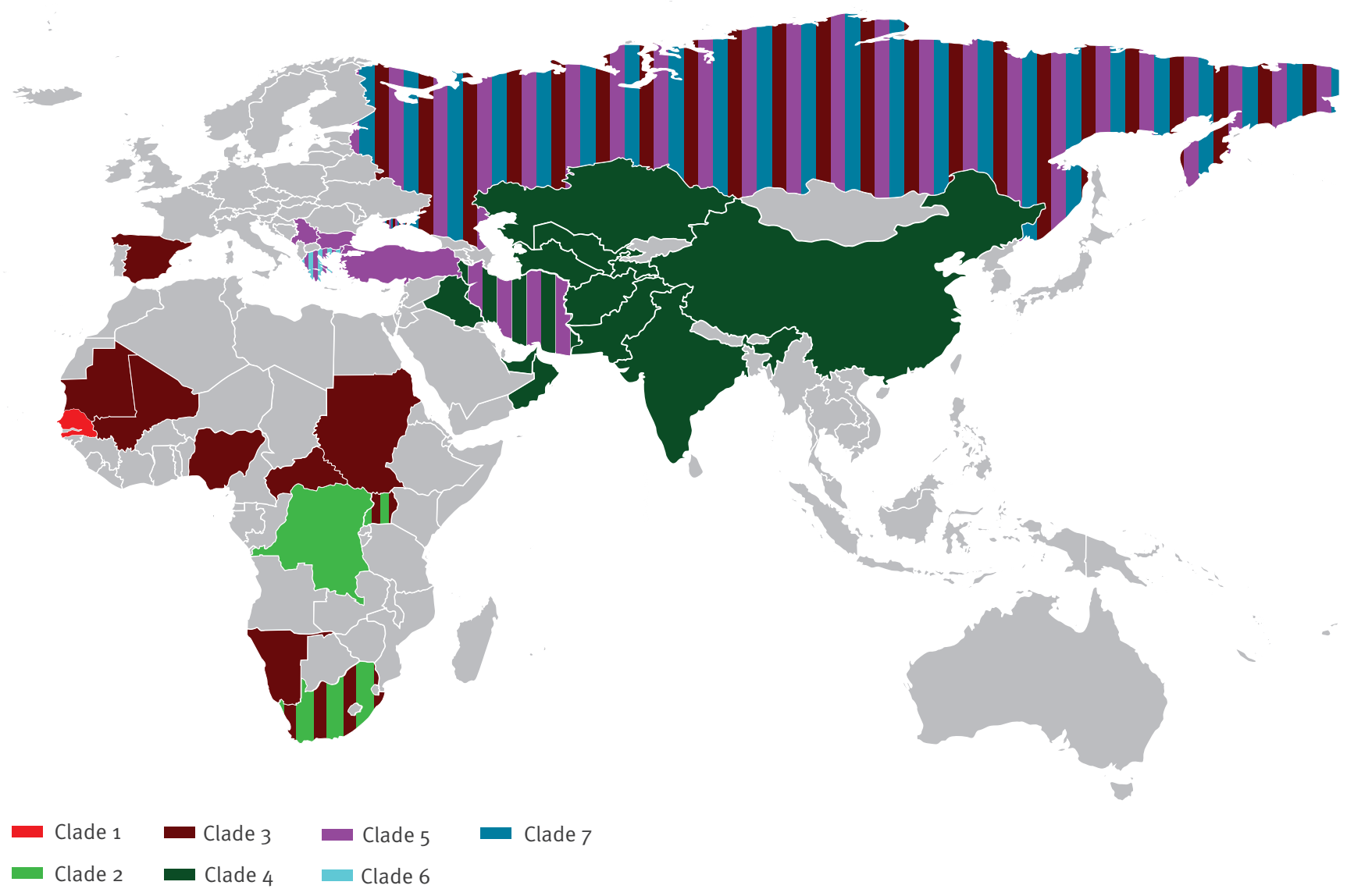

Based on all available complete S segment CCHFV genomes (163 sequences as at 5 December 2017) retrieved from GenBank.

For all strains analysed, the collection countries are presented in the following colours: Africa: clade I (red), clade II (light green) and clade III (brown); Asia: clade IV (dark green); Europe: clade V (purple), clade VI (light blue) and clade VII (blue).

ecological investigation, as well as the absence of effective prophylaxis and treatment render CCHFV a pathogen with outbreak potential [4].

Since 2000, the incidence and geographic range of CCHF cases have markedly increased $[5,6]$ following an expanding distribution of its main vector, ticks of the genus Hyalomma, specifically the Hyalomma marginatumspecies $[1,7,8]$. In Turkey, nearly 900 new CCHF cases occur annually, with a total of 9,787 cases reported from 2002-15 [9]. CCHF is endemic in the Balkan region, in Kosovo, 228 cases were reported from 1995-2013 [10], In Bulgaria, over 1,500 cases have been reported from 1952 [11]. In the European region, cases of human infection have also been reported from Albania, Russian Federation, Georgia, Greece, and Ukraine [12]. Imported cases have been reported in France [13], United Kingdom [14], Greece [15] and Germany [16]. A detailed review of other outbreaks has been recently published by Papa et al. [11].
Public health systems (including diagnostic laboratories) should be prepared to respond to the increased circulation of the virus in endemic EU countries, the potential for importation of human CCHF cases or the emergence of virus circulation in new areas e.g. Spain [17].

The objectives of this study were to amalgamate the expertise of two EU expert networks (i) EMERGE (Efficient response to highly dangerous and emerging pathogens at EU level) [18] and (ii) EVD-LabNet (Emerging Viral Diseases Laboratory Network) [19], in order to select and analyse the relevant and some of controversial aspects of CCHF disease diagnostics with implications for laboratory management of human CCHF cases and any exposed contacts.

\section{Methods}

We carried out an on line research of published paper related to CCHFV molecular detection methods. References were obtained by an online search in PubMed using an intentionally wide search-query to 
ensure that a large number of papers was retrieved also for a rare disease such as CCHF.

The query produced a large number of papers, $20 \%$ of them were discarded after a narrative review, as they did not contain a detailed description of the detection methods employed including the nucleotide sequences of primers and/or probes. The search was done by one author and the results discussed among the authors. Papers related on non-previously retrieved molecular detection methods or to others relevant aspects discussed in this report have been directly provided by experts. For phylogenetic analysis all available CCHF virus genomes by 5 December 2017 were retrieved from GenBank (https://www.ncbi.nlm.nih.gov/nucleotide), using 'txid1980519(Organism)' as term of query. All analyses have been focused only on CCHFV S-segment, because it resulted as the most conserved gene across CCHFVs $[8,20]$ and also because mostly all retrieved molecular methods has $\mathrm{S}$ segment as target. CCHF virus strains with complete $S$ segment were selected and clustered at $100 \%$ with CD-HIT v4.6. A total of 163 sequences available at 5 December 2017 were obtained and aligned with MAFFT V7.123b in local pair mode. Phylogenetic analysis were performed with RAxML v8.2.10 using GTRGAMMA model and 1000 bootstrap inferences.

A preliminary text was drafted and discussed among the experts by email and during EMERGE and EVDLabNet networks' 2017 and 2018 annual meetings. Most of the relevant and some of controversial aspects of CCHF disease with implications for laboratory management have been selected and analysed in the following sections. In the present paper, all the expressed opinions take into account both published data and personal experience of the experts.

\section{Results}

\section{Crimean-Congo haemorrhagic fever virus clades distribution}

CCHFV (family Nairoviridae, genus Orthonairovirus) is tick-borne and is maintained in a tick-vertebrate-tick cycle with Hyalomma marginatum, the main vector species in Europe. Given the wide distribution of its vector, CCHFV has been detected over a wide geographic range: Africa, Europe, Asia and the Middle East $[5,21]$.

CCHFV is an enveloped, tri-partite, negative-sense, RNA virus. The large genome segment $(\mathrm{L})$ encodes the RNAdependent RNA polymerase ( $L$ protein), the medium segment $(M)$ encodes the glycoproteins $G N$ and $G C$, while the small segment (S) encodes the nucleocapsid protein $(\mathrm{N})$.

Phylogenetic tree (Figure 1) was built, including only 65 of 163 representative strains with reported location of provenance either in GenBank records or in the associated papers. Taking into account similarity and geographic locations of the different viral lineages, seven genetic clades were identified: three prevalently diffused in Africa (clades I-III), three in Europe (clades V, $\mathrm{VI}$ and VII) and one in the south of Asia (clade IV).

Most of the isolates causing outbreaks in eastern Europe belong to clade V, whereas clade VI and VII include largely divergent strains isolated from ticks in Greece (including the prototype strain AP92) [21,22] and Russia (GenBank accession number KR814833 and KR814835).

Moreover, isolates belonging to the African clade III were collected from infected ticks in 2010 and 2014, and recently [23] a virus aligning to this clade was the cause of an outbreak in Spain [17].

For all strains analysed, the collection country was recorded and represented on the world map in Figure 2.

\section{Transmission mode}

Human infections are usually observed as single, sporadic cases when people in rural areas are bitten by ticks that have become infected by feeding on viraemic wild and domestic animals like hares, hedgehogs, horses, livestock and possibly birds [21]. The infection in animals is generally asymptomatic; at most, a mild fever may be noted.

In addition to tick exposure, CCHF infection can result from direct contact, especially through mucous membranes or skin wounds, with crushed infected ticks or the blood of infected animals (principally among shepherds, farmers, abattoir workers and veterinarians). Person-to-person transmission can also occur through contact with virus-containing bodily fluids of patients during the first $7-10$ days of illness [21]. Unprotected contact with other bodily fluids like saliva or urine, may also represent a risk for humans [24]. Nosocomial transmission to healthcare workers, transmission among patients sharing the same room [25] and possible sexual transmission $[26,27]$ have also been reported.

\section{Relevance of viraemia}

The typical duration of viraemia ranges from 1- 9 days $[28,29]$, and there is so far no evidence of detectable viraemia during the incubation period [30]. However, the positivity of CCHFV RNA in serum has been exceptionally reported up to 36 days from the onset of symptoms [31]. Studies investigating the presence and persistence of CCHFV in other body fluids are limited. Viral RNA was detectable up to 10 days and as late as 25 days after onset of symptoms in saliva [24] and urine [31] respectively, but no data on virus viability are available.

Viral load is the most important prognostic factor: a value of viraemia higher than $10^{8}$ copies $/ \mathrm{mL}$ is associated with fatal outcomes [32]. Viraemia decreases significantly over time in surviving patients, but remains persistently high in non-survivors $[32,33]$. 


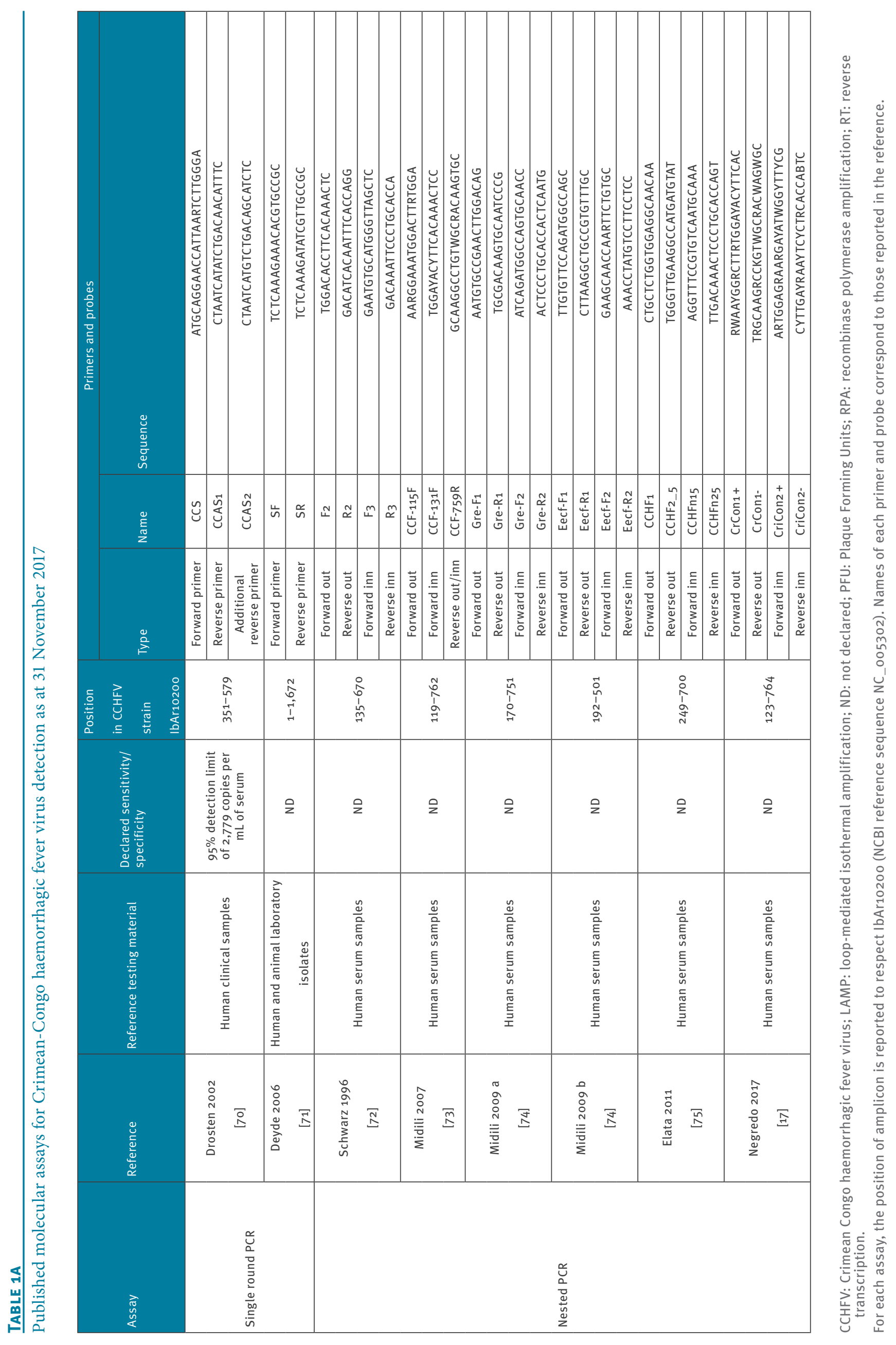




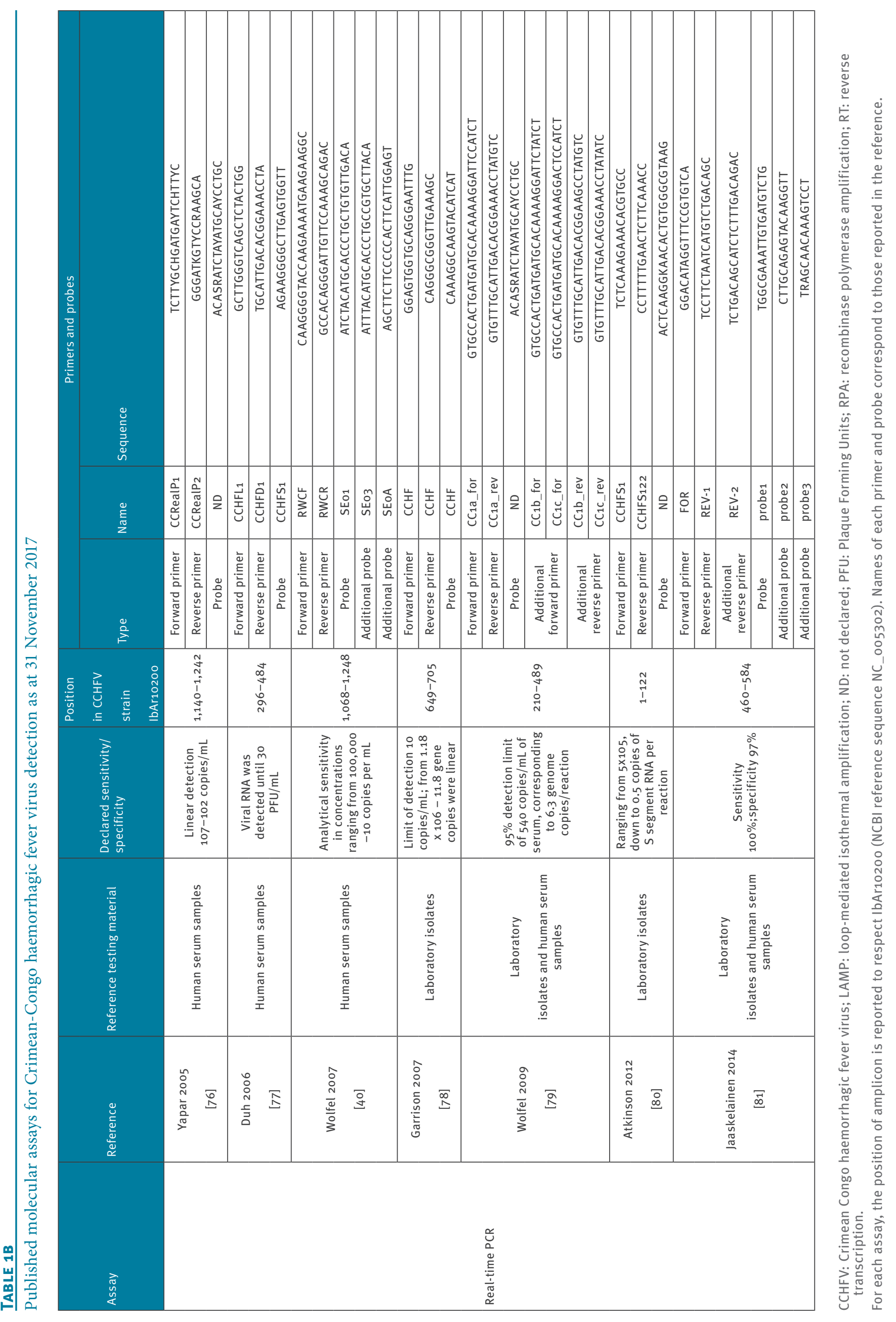




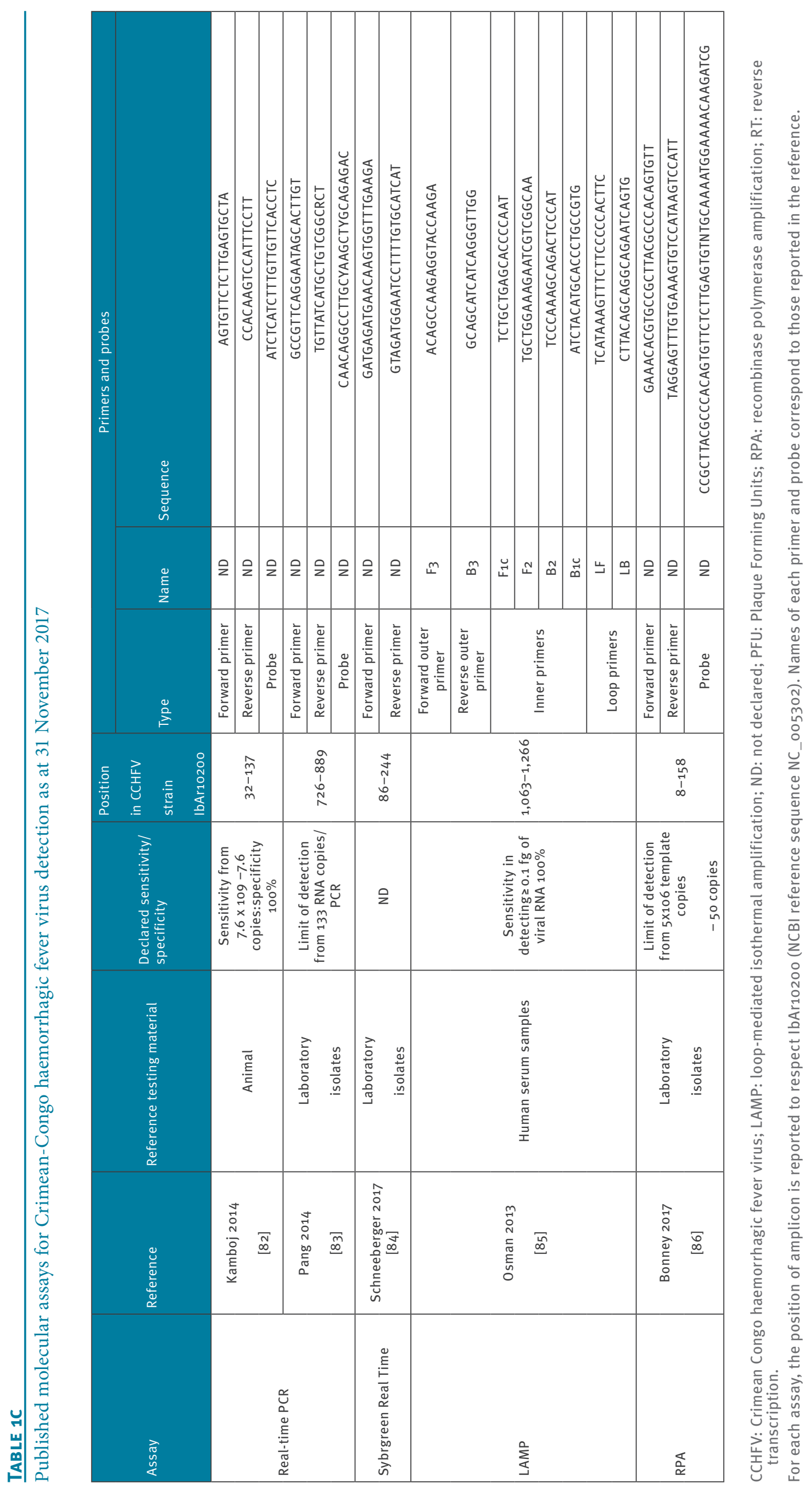


Antibody kinetics

All CCHFV genotypes belong to one serogroup [21]. Cross-reactivity between CCHFV and other nairoviruses infecting humans ( Erve virus [34]), has not been described, although monoclonal and polyclonal antibodies to the $\mathrm{N}$ protein of CCHFV were found to crossreact weakly with Dugbe virus $\mathrm{N}$ protein [35].

Nucleocapside-directed IgM antibodies have been identified as the initial serological marker during infection, becoming detectable in a median of $2-3$ days after disease onset, followed by glycoprotein precursor (GPC) directed IgM (4-6 days) and IgG antibodies (5-6 days) [28]. In another report, CCHFV IgM was detectable from 4 days after the onset of disease for up to 4 months. The maximum level of antibody titres was usually reached in the second to third week of illness [1]. IgM titre typically declines to undetectable levels 4 months after the onset of symptoms [29].

IgG seroconversion occurs 1-2 days after the IgM response [28] and IgG antibody remains detectable for at least 5 years $[29,36]$.

Antibody production against CCHFV is an important prognostic indicator for survival [37]. Patients with fatal outcome rarely develop measurable antibody responses (reviewed in [37]) and Saksida et al. observed a reverse correlation between viral load and antibody levels in fatal CCHF cases [33], indicating that an impaired immune response leads to uncontrolled replication of the virus. High levels of interleukin-10 (IL-10), an anti-inflammatory cytokine, were detected in patients with fatal outcomes and were lowest in patients with a moderate disease course [33]. It was hypothesised that CCHF could be the result of a delayed and downregulated immune response caused by IL-10, which leads to an increased replication and spread of CCHFV throughout the body [33].

\section{Biosafety}

CCHFV is classified as a risk group 4 pathogen. The virus is stable under wet conditions for 7 hours at $37^{\circ} \mathrm{C}, 11$ days at $20^{\circ} \mathrm{C}$ and 15 days at $4^{\circ} \mathrm{C}$ [20]. Under dry conditions, it is stable for at least $90 \mathrm{~min}$, but less than 24 hours.

However, there is an ongoing debate about the absolute requirement of biosafety levels 4 (BSL4) for handling the virus [38]. Many endemic countries need to work with the virus despite the absence of BSL4 infrastructure. Biosafety and biosecurity procedures are essential for the safe and appropriate management of specimens from suspected/confirmed CCHF patients. All laboratories should refer to national guidelines on the documents 'CWA 15793:2011 Laboratory bio-risk management' and 'CWA 16393:2012 Laboratory biorisk management - Guidelines for the implementation of CWA 15793:2008' for a complete guide [39]. The European Check List for Laboratory Biorisk Management developed in the framework of the Joint Actions Quality
Assurance Exercises and Networking on the Detection of Highly Infectious Pathogens (QUANDHIP) project can be helpful for the implementation and evaluation of biorisk management approaches [40].

\section{Inactivation}

Like all lipid-enveloped viruses, CCHFV can be readily inactivated by common fixatives such as $2 \%$ glutaraldehyde [41], formalin and paraformaldehyde; chlorinebased disinfectants, such as $1 \%$ sodium hypochlorite $[41,42]$; and other disinfectants, such as hydrogen peroxide and peracetic acid $[43,44]$. Physical inactivation is also effective, like high temperature $\left(56^{\circ} \mathrm{C}\right.$ for 30 min or $60^{\circ} \mathrm{C}$ for $\left.15 \mathrm{~min}\right)$ [41], Ultraviolet $(1,200$ to 3,000 $\mu \mathrm{W} / \mathrm{cm}^{2}$ ) or low $\mathrm{pH}$ (less than 6) $[43,45]$. The virus does not survive in matured meat (due to low $\mathrm{pH}$ ) and is also inactivated in $40 \%$ ethanol within $2 \mathrm{~min}[20]$.

There is a general agreement among the consulted experts that a critical aspect for laboratory biosafety and operation is the proper and reliable inactivation of specimens before they can be removed from the highlevel biocontainment environment for further diagnostic testing. Some of these inactivation methods include (i) chemical treatment (i.e. Buffer AVL or Buffer RLT, Qiagen, Hilden, Germany) $+100 \%$ ethanol, SDS, $0.5 \%$ Tween-20 (Thermofisher, Waltham, Massachusetts, USA) $[46,47]$ or (ii) heat treatment plus riboflavin (vita$\min B_{2}$ ) [48].

It is opinion of the experts that further evaluation of inactivation procedures are needed, especially for their impact on other laboratory tests necessary for clinical evaluation and increased survival rates of patients. Although there is no direct evidence of its effects on CCHFV, it has been shown that Triton X-100 (SigmaAldrich, Saint Louis, Missouri, USA can decrease the biohazard risk of performing laboratory tests on samples from patients infected with other haemorrhagic fever viruses (i.e. Ebola), without affecting the results of biochemical tests [49-52].

Transport of diagnostic samples

General guidelines for suspected viral haemorrhagic fever infections apply for the transport of diagnostic samples from CCHF-suspected cases; these are listed under guidelines as Category A, Infectious Substances Affecting Humans UN 2814 and must be transported in packaging that meets the United Nations class 6.2 specifications and complies with Packing Instruction P620 [53].

Additionally, as for other biological resources, the exchange of CCHF samples or virus strains needs to comply with the Nagoya protocol on access to genetic resources and the fair and equitable sharing of benefits arising from their utilisation, which regulates transnational exchange between countries [54]. 
TABLE 2

Commercial serological assays for Crimean-Congo haemorrhagic fever virus detection as at 5 December 2017

\begin{tabular}{|c|c|c|c|}
\hline Assay & Detection mode & Diagnostic kit producers & Comments/Target antigen \\
\hline $\operatorname{IgG}$ ELISA & & \multirow{3}{*}{ Vector-Best, Novosibirsk, Russia } & \multirow{3}{*}{ Unknown } \\
\hline IgM ELISA & Qualitative & & \\
\hline $\begin{array}{l}\text { IgG IFA test } \\
\text { Ag detection }\end{array}$ & & & \\
\hline IgG ELISA & Qualitative & \multirow{3}{*}{ Euroimmun, Luebeck, Germany } & \multirow{3}{*}{ CCHFV GPC and CCHFV N } \\
\hline IgM ELISA & & & \\
\hline IgG IFA & & & \\
\hline IgG ELISA & & \multirow{3}{*}{$\begin{array}{l}\text { Crimean-Congo ELISA Kits, Diagen } \\
\text { Biyoteknolojik Sistemleri A.Ş., Ankara, Turkey }\end{array}$} & \multirow{3}{*}{ Unknown } \\
\hline IgM ELISA & Quantitative & & \\
\hline Ag ELISA & & & \\
\hline IgG ELISA & Qualitative & \multirow{3}{*}{ Abbexa Ltd, Cambridge, United Kingdom } & \multirow{3}{*}{$\begin{array}{l}\text { For research use only, not for } \\
\text { diagnostic use. }\end{array}$} \\
\hline IgM ELISA & & & \\
\hline Elisa & & & \\
\hline IgG ELISA & Quantitative & \multirow{3}{*}{$\begin{array}{c}\text { Alpha Diagnostic Intl. Inc., San Antonio, Texas, } \\
\text { United States(US) }\end{array}$} & \multirow{3}{*}{$\begin{array}{l}\text { For research use only, not for } \\
\text { diagnostic or therapeutic use } \\
\text { CCHFV NP }\end{array}$} \\
\hline IgM ELISA & Quantitative & & \\
\hline IgA, IgG, IgM ELISA & Qualitative & & \\
\hline IgG ELISA & Qualitative & \multirow{2}{*}{$\begin{array}{l}\text { ELISA Kit, Antibody-Sunlong Biotech Co.,Ltd, } \\
\text { Hangzhou, Zhejiang, China }\end{array}$} & \multirow{2}{*}{ Unknown } \\
\hline ELISA & & & \\
\hline IgG ELISA & Qualitative & \multirow{2}{*}{ Creative Diagnostics, Shirley, New York, USA } & \multirow{2}{*}{ CCHFV NP } \\
\hline IgM ELISA & Quantitative, qualitative & & \\
\hline
\end{tabular}

CCHFV: Crimean-Congo haemorrhagic fever virus; ELISA: enzyme-linked immunosorbent assay; IFA: immunofluorescent assay; USA: United States of America.

\section{Diagnosis}

The choice of which CCHF detection assays should be used for diagnostics with maximum sensitivity and specificity depends on the stage of disease and the specimens available.

Laboratory diagnosis of a patient with a clinical history compatible with CCHF is generally performed during the acute phase of the disease by viral RNA (RT-PCR) detection in blood [21]. In addition to blood (serum, plasma or whole blood), other possible specimens for molecular detection are saliva, urine [24,32] or post mortem biopsy of the liver and bodily fluids (including semen, for infection control purposes) $[26,27]$.

The available data, limited to very few patients, do not allow detailed comparisons of the sensitivity of RT-PCR detection methods performed on different sample types and, in particular, of urine and saliva vs serum samples. In two of six infected patients reported in a review of CCHF cases in Kosovo* [31], viraemia was detectable up to 30 days after the onset of symptoms. In the same investigation, one patient's urine was PCR-positive before the serum, and in another patient viruria continued longer than viraemia; however, more detailed studies on viruria are required. Further, both viruria and viraemia are detectable several days after the appearance of IgG response [31]. No chronological data are provided about detection of CCHFV RNA in saliva [24].

During the small outbreak in Spain involving two patients in 2016, positive RT-PCR results were obtained via saliva and vaginal swab, but they became negative when viraemia was still detectable [17]. Virus isolation was attempted from these samples, but was not successful (Maria Paz Sanchez-Seco, personal communication, EVD-LabNet $2^{\text {nd }}$ annual meeting, Rotterdam October 2017).

\section{Molecular detection}

There is high genetic diversity within the different CCHFV strains (Figure 1), which consequently hampers the performance of molecular tests. As a result, a range of different methods employing varied primer/probe combinations have been developed and a truly universal assay has been difficult to devise. Table 1 lists published molecular assays retrieved by our PubMed search: two single round $P C R$, six nested $P C R, 10$ realtime $P C R$, one loop-mediated isothermal amplification (LAMP) and one recombinase polymerase amplification (RPA). Indication on reference testing materials and sensitivity/specificity of the tests are also reported, when declared.

Therefore there is an agreement of experts that is advisable to perform more than one test to avoid exclusive 


\section{BoX}

Criteria proposed for laboratory confirmation of a clinically suspected Crimean Congo haemorrhagic fever case

For laboratory confirmation of a clinical CCHF diagnosis, the expert group opinion is that a CCHFV infection is laboratory confirmed when at least one criteria in the Box is fulfilled.

- Detection by molecular tests of CCHFV RNA, in blood (whole blood, serum or plasma) or in other bodily fluids or tissues;

- Detection of CCHFV IgM or relevant (fourfold) increase in CCHFV IgG titres between two serologic samples (acute and convalescence phases);

- CCHFV isolation and/or detection of CCHF viral antigens in blood (whole blood, serum or plasma).

CCHFV: Crimean Congo haemorrhagic fever virus.

reliance on a single assay and a single target, taking into account the travel history and the geographic distribution of the different strains.

\section{Serological assays}

In published investigations, the methods employed for the detection of antibodies are indirect immunofluorescence assays (IFAs) and enzyme-linked immunosorbent assays (ELISAs) [55-57]. Several commercial kits are available (Table 2), but only the performance of VectorBest CCHF ELISA and Euroimmun CCHF IFA have been tested in a collaborative study conducted by reference centres for CCHF laboratory diagnosis and surveillance in their respective countries [58]. The IgM sensitivity for ELISA and IFA assays were $87.8 \%(95 \% \mathrm{Cl}: 78.6-$ 96.9). and $93.9 \%$ (95\% Cl: $85.8-100.0)$, respectively. For IgG assays, reported sensitivities were $80.4 \%$ (95\% Cl: 69.5-91.3) for ELISA and 86.1\% (95\% Cl: 74.8-97.4) for IFA. The overall specificity was estimated at $100 \%$ for all the tests.

A CCHFV seroneutralisation test is not normally performed for diagnostic purposes; it requires work with an infectious virus, necessitating a BSL4 laboratory, and is difficult to perform. However, reverse genetic approaches employing non-infectious reporter viruses have been described recently [59], enabling neutralisation to be performed at low containment.

\section{Virus isolation}

Viral isolation, i.e. from blood or organ for further characterisation or infectivity studies, is performed under BSL4 conditions on either LLC-MK2, Vero, BHK-21 or SW-13.4 cell lines and can be achieved in 2-10 days [6o]. CCHFV generally produces no or little cytopathogenic effect and viral growth can be detected by IFA with specific monoclonal antibodies [41] or by molecular tests. When viral isolation on cell cultures fails, it can be attempted in new-born or immunodeficient mice.
FIGURE 3

Algorithm for molecular diagnosis of Crimean-Congo haemorrhagic fever acute infection based on expert opinion

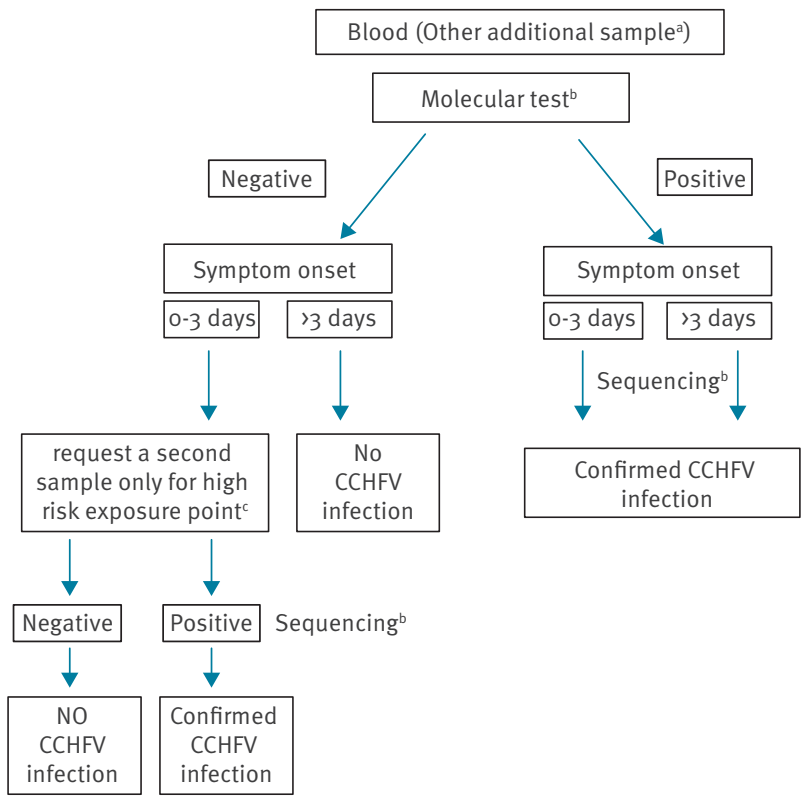

CCHFV: Crimean-Congo haemorrhagic fever virus.

a The preferred biological specimen is blood (serum, plasma or whole blood). Other possible biological specimens are saliva, urine $[24,31]$ and post-mortem biopsy or bodily fluids (including semen, for infection control purposes $[26,27])$.

${ }^{b}$ It is preferable that at least two different targets are tested: The first molecular test should target the S segment, while the second assay should be performed in a different genome region to confirm the absence or presence of CCHF infection, in case of negative result.

'Sequencing is indicated for viral characterisation and cluster identification, as well as for the confirmation of first cases detected or of discordant results of molecular tests.

d The molecular test to be performed should take into account epidemiological data.

It is preferable that viral isolation is performed on samples collected during the first 5 days of infection, when the viraemia levels are high $[58,61]$.

\section{Laboratory diagnosis of CCHFV infection}

There is no official, agreed-upon case definition for CCHF in the EU, though several case definitions adopted by EU countries were reviewed by the European Centre for Disease Prevention and Control (ECDC) [62,63]. According to a report published by ECDC in 2014 [6o], most countries used, at least for surveillance purposes, the EU case definition established for Viral Haemorrhagic Fever [64].

Taking into account that laboratory screening is usually performed using molecular methods, we propose as expert opinion the following molecular diagnostic 
algorithm for patients with suspected CCHF infection (Figure 3). However, it is advisable, especially when the molecular tests are negative, to perform also serological tests on all suspected patients.

Other relevant aspects related to management of CCHF patients as clinical manifestation and discharging criteria are reported in the Supplementary material.

\section{Discussion}

CCHF is an important global health threat, as underlined by its inclusion in the list of priority diseases in the WHO document 'An R \& D blueprint for action to prevent epidemics' [65].

In Europe, two autochthonous cases in Spain in 2016 [17] and the observed risk of importation of travelassociated cases [66] reinforce the notion that public health systems must be ready to respond to a potential emergence of CCHF.

Prompt and accurate laboratory diagnosis during the first days of the disease is critical to improve patient management, guide infection control measures and reduce case fatality. Early detection of viral RNA in blood is considered the gold standard diagnostic approach in the acute phase of the disease [21]. While the CCHFV RNA RT-PCR diagnostic test is most commonly performed in specialised laboratories, where non-commercial diagnostic assays and related reference biological material are available, this capability is more limited in rural areas and small cities where the majority of reported cases have occurred [9]. The availability of simple to use, commercial diagnostic tests will increase the number of laboratories performing RT-PCR or a similar NA detection strategy. However, laboratory capacity does not automatically mean capability, and laboratories implementing such tests would benefit from external quality assessments (EQA) of their capability to detect CCHFV in clinical samples, including monitoring of the effects of any corrective actions taken. The difficulty of clinical laboratories in establishing the diagnosis a CCHFV infection underlines the need to perform confirmatory tests in reference laboratories for both positive and negative samples collected from patients suspected of CCHF infection.

In addition, appropriate biosafety measures must be in place when performing molecular testing.

\section{Proposed measures to improve CCHFV laboratory preparedness and response}

Measures to improve CCHFV laboratory preparedness and response should include: improving molecular tests to overcome the lack of sensitivity due to the high variability of the CCHFV genome; providing a positive control panel for molecular diagnostics, including the different CCHFV genotypes (including for serology testing) in order to support the improvement of diagnostic capability of clinical laboratories; enrolling diagnostic laboratories appointed for CCHFV diagnostics regularly in EQA programmes; improvement of diagnostic algorithms building on clinical experiences; validation of procedures to inactivate infectivity of clinical samples; and establishing of an international biorepository for the collection and storing of clinical samples, with the aim of validating new diagnostic tests and supporting pathogenicity studies. Some of these activities, including the evaluation of laboratory capability [67] and EQA [68] in particular, have been performed within the framework of EMERGE and EVDLabNet and earlier as part of EU-funded projects such as EuronetP4 (Grant No. 2003214), EnP4Lab (Grant No. 2006208), QUANDHIP (Grant No. 20102102) and ENIVD (Framework Service Contract ref. no. ECDC/2008/011. Similar support of other collaborating EU projects, such as the European Virus Archive (EVAg), could meet these needs in the future.

\section{Conclusions}

There are knowledge gaps concerning the putative persistence of the CCHFV in various body compartments of survivors and the related consequences for infection transmission. Basic knowledge is needed to provide evidence to better inform hospital discharge guidelines and these issues need further research. Furthermore, a One Health approach is required for adequate public health preparedness for CCHF, and relevant measures should include vector and animal surveillance, focusing particularly on migratory birds $[5,9,69]$. Greater awareness of the circulation of CCHFV in vectors/animals in specific geographic areas is fundamental in order to alert public health systems. Information on the circulation of CCHFV can be obtained by a syndromic approach and by including CCHFV testing in the diagnostic algorithm of severe febrile infectious diseases of unknown origin.

Until an effective vaccine and/or therapeutics have been developed, the CCHFV outbreak response will continue to rely on rapid identification and appropriate infection-control measures. Front-line hospitals, as well as reference laboratories, have a crucial role in the outbreak response, which should integrate laboratory, clinical and public health responses.

Note

*This designation is without prejudice to positions on status, and is in line with United Nations Security Council Resolution $1244 / 99$ and the International Court of Justice Opinion on the Kosovo Declaration of Independence.

\section{Acknowledgements}

This work was supported by the Health programme 20142020, from the European Commission; EMERGE Joint Action grant number: 677066. INMI received 'Ricerca Corrente, Linea 1, Patogeni ad alto impatto sociale, emergenti, tropicali, MDR, negletti' grants from the Italian Ministry of Health. This work was supported by the European Centre for Disease Prevention and Control (ECDC) under the EVDLabNet Framework contract ECDC/2016/002. This work was supported by the CCHVaccine project 2 'the European 
Union's Horizon 2020 research and innovation program', grant agreement no. 732732 .

\section{Conflict of interest}

None declared.

\section{Authors' contributions}

BB data analysis, coordinating the activities and writing manuscript; GCEM data analysis and writing manuscript; $C B R$ and $A D C$ study coordinator, data analysis and writing manuscript. BB, CEMG, MK, TA, SB, IC, RG, RH, GK, CML, AM, AP, MPSS, AVS, HZ, CN, MRC, GI, CBR, and ADC contributed to the conception and design of the work, the interpretation of data, the revision of the manuscript and the approval of the final version.

\section{References}

1. Mertens M, Schmidt K, Ozkul A, Groschup MH. The impac of Crimean-Congo hemorrhagic fever virus on public health. Antiviral Res. 2013;98(2):248-60. https://doi.org/10.1016/j. antiviral.2013.02.007 PMID: 23458713

2. Dreshaj S, Ahmeti S, Ramadani N, Dreshaj G, Humolli I, Dedushaj I. Current situation of Crimean-Congo hemorrhagic fever in Southeastern Europe and neighboring countries: a public health risk for the European Union? Travel Med Infect Dis. 2016;14(2):81-91. https://doi.org/10.1016/j. tmaid.2016.03.012 PMID: 27044611

3. Yon L, Duff JP, Ågren EO, Erdélyi K, Ferroglio E, Godfroid J, et al. Recent changes in infectious diseases in European wildlife. J Wildl Dis. 2018; (Forthcoming). PMID: 30284963

4. Nisii C, Grunow R, Brave A, Ippolito G, Jacob D, Jureen P, et al. EMERGE Viral Pathogens Working Group. Prioritization of High Consequence Viruses to Improve European Laboratory Preparedness for Cross-Border Health Threats. Adv Exp Med Biol. 2017;972:123-9. https://doi.org/10.1007/5584_2016_152 PMID: 28032326

5. Al-Abri SS, Abaidani IA, Fazlalipour M, Mostafavi E, Leblebicioglu $\mathrm{H}$, Pshenichnaya N, et al. Current status of Crimean-Congo haemorrhagic fever in the World Health Organization Eastern Mediterranean Region: issues, challenges, and future directions. Int J Infect Dis. 2017;58:82-9. https://doi.org/10.1016/j.ijid.2017.02.018 PMID: 28259724

6. Papa A, Weber F, Hewson R, Weidmann M, Koksal I, Korukluoglu G, et al. Meeting report: First International Conference on Crimean-Congo hemorrhagic fever. Antiviral Res. 2015;120:57-65. https://doi.org/10.1016/j. antiviral.2015.05.005 PMID: 26022198

7. Gargili A, Estrada-Peña A, Spengler JR, Lukashev A, Nuttall PA, Bente DA. The role of ticks in the maintenance and transmission of Crimean-Congo hemorrhagic fever virus: A review of published field and laboratory studies. Antiviral Res. 2017;144:93-119. https://doi.org/10.1016/j. antiviral.2017.05.010 PMID: 28579441

8. Papa A, Tsergouli K, Tsioka K, Mirazimi A. Crimean-Congo Hemorrhagic Fever: Tick-Host-Virus Interactions. Front Cell Infect Microbiol. 2017;7:213. https://doi.org/10.3389/ fcimb.2017.00213 PMID: 28603698

9. Leblebicioglu H, Ozaras R, Irmak H, Sencan I. CrimeanCongo hemorrhagic fever in Turkey: Current status and future challenges. Antiviral Res. 2016;126:21-34. https://doi. org/10.1016/j.antiviral.2015.12.003 PMID: 26695860

10. Fajs L, Jakupi X, Ahmeti S, Humolli I, Dedushaj I, Avšič-Županc T. Molecular epidemiology of Crimean-Congo hemorrhagic fever virus in Kosovo. PLoS Negl Trop Dis. 2014;8(1):e2647. https://doi.org/10.1371/journal.pntd.0002647 PMID: 24416468

11. Spengler JR, Bente DA, Bray M, Burt F, Hewson R, Korukluoglu $\mathrm{G}$, et al. Second International Conference on Crimean-Congo Hemorrhagic Fever. Antiviral Res. 2018;150:137-47. https://doi. org/10.1016/j.antiviral.2017.11.019 PMID: 29199036

12. European Centre for Disease Prevention and Control (ECDC). Annual Epidemiological Report 2016 - Crimean-Congo haemorrhagic fever. Stockholm: ECDC. 2016. Available from: https://ecdc.europa.eu/sites/portal/files/documents/ CrimeanCongo\%2ohaemorrhagic\%2ofever\%20AER.pdf
13. Jauréguiberry S, Tattevin P, Tarantola A, Legay F, Tall A, Nabeth P, et al. Imported Crimean-Congo hemorrhagic Fever. J Clin Microbiol. 2005;43(9):4905-7. https://doi.org/10.1128/ JCM.43.9.4905-4907.2005 PMID: 16145173

14. Lumley S, Atkinson B, Dowall S, Pitman J, Staplehurst S, Busuttil J, et al. Non-fatal case of Crimean-Congo haemorrhagic fever imported into the United Kingdom (ex Bulgaria), June 2014. Euro Surveill. 2014;19(30):20864. https://doi.org/10.2807/1560-7917.ES2014.19.30.20864 PMID: 25108534

15. Papa A, Markatou F, Maltezou HC, Papadopoulou E, Terzi E, Ventouri S, et al. Crimean-Congo haemorrhagic fever in a Greek worker returning from Bulgaria, June 2018. Euro Surveill. 2018;23(35):1800432. https://doi.org/10.2807/1560-7917. ES.2018.23.35.1800432 PMID: 30180928

16. Conger NG, Paolino KM, Osborn EC, Rusnak JM, Günther S, Pool J, et al. Health care response to CCHF in US soldier and nosocomial transmission to health care providers, Germany, 2009. Emerg Infect Dis. 2015;21(1):23-31. https://doi. org/10.3201/eid2101.141413 PMID: 25529825

17. Negredo A, de la Calle-Prieto F, Palencia-Herrejón E, Mora-Rillo M, Astray-Mochales J, Sánchez-Seco MP, et al. Crimean Congo Hemorrhagic Fever@Madrid Working Group. Autochthonous Crimean-Congo Hemorrhagic Fever in Spain. N Engl J Med. 2017;377(2):154-61. https://doi.org/10.1056/NEJMoa1615162 PMID: 28700843

18. Efficient response to highly dangerous and emerging pathogens at EU level (Emerge). Berlin: Emerge; 2018. Available from: http://www.emerge.rki.eu/Emerge/EN/Home/ Homepage_node.html

19. EVD-LabNet. Rotterdam: EVD-Labnet. [Accessed 21 Jun 2018]. Available from: https://www.evd-labnet.eu

20. Hardestam J, Simon M, Hedlund KO, Vaheri A, Klingström J, Lundkvist $A$. Ex vivo stability of the rodent-borne Hantaan virus in comparison to that of arthropod-borne members of the Bunyaviridae family. Appl Environ Microbiol. 2007;73(8):254751. https://doi.org/10.1128/AEM.02869-06 PMID: 17337567

21. Bente DA, Forrester NL, Watts DM, McAuley AJ, Whitehouse CA, Bray M. Crimean-Congo hemorrhagic fever: history, epidemiology, pathogenesis, clinical syndrome and genetic diversity. Antiviral Res. 2013;100(1):159-89. https://doi. org/10.1016/j.antiviral.2013.07.006 PMID: 23906741

22. Papa A, Chaligiannis I, Kontana N, Sourba T, Tsioka K, Tsatsaris $A$, et al. A novel AP92-like Crimean-Congo hemorrhagic fever virus strain, Greece. Ticks Tick Borne Dis. 2014;5(5):590-3. https://doi.org/10.1016/j.ttbdis.2014.04.008 PMID: 24953797

23. Cajimat MNB, Rodriguez SE, Schuster IUE, Swetnam DM, Ksiazek TG, Habela MA, et al. Genomic Characterization of Crimean-Congo Hemorrhagic Fever Virus in Hyalomma Tick from Spain, 2014. Vector Borne Zoonotic Dis. 2017;17(10):7149. https://doi.org/10.1089/vbz.2017.2190 PMID: 28836897

24. Bodur H, Akinci E, Ongürü P, Carhan A, Uyar Y, Tanrici A, et al. Detection of Crimean-Congo hemorrhagic fever virus genome in saliva and urine. Int J Infect Dis. 2010;14(3):e247-9. https:// doi.org/10.1016/j.ijid.2009.04.018 PMID: 19656706

25. Gürbüz Y, Sencan I, Oztürk B, Tütüncü E. A case of nosocomial transmission of Crimean-Congo hemorrhagic fever from patient to patient. Int J Infect Dis. 2009;13(3):e105-7. https://doi. org/10.1016/j.ijid.2008.08.002 PMID: 18948048

26. Pshenichnaya NY, Sydenko IS, Klinovaya EP, Romanova EB, Zhuravlev AS. Possible sexual transmission of Crimean-Congo hemorrhagic fever. Int J Infect Dis. 2016;45:109-11. https://doi. org/10.1016/j.ijid.2016.02.1008 PMID: 26972040

27. Ergonul 0, Battal I. Potential sexual transmission of Crimean-Congo hemorrhagic fever infection. Jpn J Infect Dis. 2014;67(2):137-8. https://doi.org/10.7883/yoken.67.137 PMID: 24647261

28. Ergunay K, Kocak Tufan Z, Bulut C, Kinikli S, Demiroz AP, Ozkul A. Antibody responses and viral load in patients with Crimean-Congo hemorrhagic fever: a comprehensive analysis during the early stages of the infection. Diagn Microbiol Infect Dis. 2014;79(1):31-6. https://doi.org/10.1016/j. diagmicrobio.2013.12.015 PMID: 24630756

29. Ergönül O. Crimean-Congo haemorrhagic fever. Lancet Infect Dis. 2006;6(4):203-14. PMID: 16554245

30. Tishkova FH, Belobrova EA, Valikhodzhaeva M, Atkinson B, Hewson R, Mullojonova M. Crimean-Congo hemorrhagic fever in Tajikistan. Vector Borne Zoonotic Dis. 2012;12(9):722-6. https://doi.org/10.1089/vbz.2011.0769 PMID: 22217164

31. Thomas S, Thomson G, Dowall S, Bruce C, Cook N, Easterbrook L, et al. Review of Crimean Congo hemorrhagic fever infection in Kosova in 2008 and 2009: prolonged viremias and virus detected in urine by PCR. Vector Borne Zoonotic Dis. 2012;12(9):800-4. https://doi.org/10.1089/vbz.2011.0776 PMID: 22925025 
32. Hasanoglu I, Guner R, Carhan A, Kocak Tufan Z, Yagci-Caglayik $D$, Guven T, et al. Crucial parameter of the outcome in Crimean Congo hemorrhagic fever: Viral load. J Clin Virol. 2016;75:42-6. https://doi.org/10.1016/j.jcv.2015.12.006 PMID: 26780111

33. Saksida A, Duh D, Wraber B, Dedushaj I, Ahmeti S, AvsicZupanc T. Interacting roles of immune mechanisms and viral load in the pathogenesis of crimean-congo hemorrhagic fever. Clin Vaccine Immunol. 2010;17(7):1086-93. https://doi. org/10.1128/CVI.00530-09 PMID: 20484568

34. Dilcher M, Koch A, Hasib L, Dobler G, Hufert FT, Weidmann M. Genetic characterization of Erve virus, a European Nairovirus distantly related to Crimean-Congo hemorrhagic fever virus. Virus Genes. 2012;45(3):426-32. https://doi.org/10.1007/ S11262-012-0796-8 PMID: 22864548

35. Ward VK, Marriott AC, Polyzoni T, el-Ghorr AA, Antoniadis A, Nuttall PA. Expression of the nucleocapsid protein of Dugbe virus and antigenic cross-reactions with other nairoviruses. Virus Res. 1992;24(2):223-9. https://doi.org/10.1016/01681702(92)90009-X PMID: 1529645

36. Zeller H. Laboratory diagnosis of crimean congo hemorrhagic fever. In: O. Ergonul, C.A. Whitehouse, editors. Crimean Congo Hemorrhagic Fever: A Global Perspective. Dordrecht, NL: Springer; 2007. p. 233-243.

37. Akıncı E, Bodur H, Leblebicioglu H. Pathogenesis of CrimeanCongo hemorrhagic fever. Vector Borne Zoonotic Dis. 2013;13(7):429-37. https://doi.org/10.1089/vbz.2012.1061 PMID: 23663164

38. Weidmann M, Avsic-Zupanc T, Bino S, Bouloy M, Burt F, Chinikar S, et al. Biosafety standards for working with Crimean-Congo hemorrhagic fever virus. J Gen Virol. 2016;97(11):2799-808. https://doi.org/10.1099/jgv.0.000610 PMID: 27667586

39. European Committee for Standardisation (CEN). CWA 15793:2011 D/E/F. CEN Workshop Agreement. Brussels: CEN; 2011. Available from: http://www.cen.eu/CEN/sectors/ technicalcommitteesworkshops/workshops/Pages/ws31.aspx

40. Efficient response to highly dangerous and emerging pathogens at EU level (Emerge). Integrated European Checklist for Laboratory Biorisk Management in Handling of High Consequence Risk Group 3 and 4 Agents (ECL-Biorisk). Berlin: Emerge; 2016. Available from: https://www.emerge.rki.eu/ Emerge/EN/Content/Topics/Rules/ECL_Biorisk.html

41. Appannanavar SB, Mishra B. An update on crimean congo hemorrhagic Fever. J Glob Infect Dis. 2011;3(3):285-92. https:// doi.org/10.4103/0974-777X.83537 PMID: 21887063

42. Smither S, Phelps A, Eastaugh L, Ngugi S, O’Brien L, Dutch A, et al. Effectiveness of Four Disinfectants against Ebola Virus on Different Materials. Viruses. 2016;8(7):E185. https://doi. org/10.3390/v8070185 PMID: 27399759

43. Krauss H, Weber A, Appel M, Enders B, Isenberg HD, Schiefer $\mathrm{HG}$, et al. Viral zoonoses. Zoonoses. Infectious Diseases Transmissible from Animals to Humans. 3rd ed. Washington, D.C: ASM Press; 2013. p. 172.

44. Stadtlander CTKH. Control of Communicable Diseases Manual. David L. Heymann. Washington DC, USA: American Public Health Association, 18th (edn). Int J Epidemiol. 2004;34(6):35-7.

45. Hoogstraal H. The epidemiology of tick-borne Crimean-Congo hemorrhagic fever in Asia, Europe, and Africa. J Med Entomol. 1979;15(4):307-417. https://doi.org/10.1093/jmedent/15.4.307 PMID: 113533

46. Haddock E, Feldmann F, Feldmann H. Effective Chemical Inactivation of Ebola Virus. Emerg Infect Dis. 2016;22(7):1292 4. https://doi.org/10.3201/eid2207.160233 PMID: 27070504

47. Cutts T, Grolla A, Jones S, Cook BW, Qiu X, Theriault SS. Inactivation of Zaire ebolavirus Variant Makona in Human Serum Samples Analyzed by Enzyme-Linked Immunosorbent Assay. J Infect Dis. 2016;214(suppl 3):S218-21. https://doi. org/10.1093/infdis/jiw289 PMID: 27571899

48. Cap AP, Pidcoke HF, Keil SD, Staples HM, Anantpadma M, Carrion R Jr, et al. Treatment of blood with a pathogen reduction technology using ultraviolet light and riboflavin inactivates Ebola virus in vitro. Transfusion. 2016;56(Suppl 1):S6-15. https://doi.org/10.1111/trf.13393 PMID: 27001363

49. Lau R, Wang A, Chong-Kit A, Ralevski F, Boggild AK. Evaluation of Ebola virus inactivation procedures for Plasmodium falciparum malaria diagnostics. J Clin Microbiol. 2015;53(4):1387-90. https://doi.org/10.1128/JCM.00165-15 PMID: 25631810

50. Mifsud A, Peelen D, Brincat P, Abela S, Debattista N, Laspina $\mathrm{S}$, et al. A feasibility study on the effects of Triton X-10o for the in vitro inactivation of Ebola virus on haematological assays. J Clin Pathol. 2016;69(7):637-42. https://doi.org/10.1136/ jclinpath-2015-203331 PMID: 26670745

51. Tempestilli M, Pucci L, Notari S, Di Caro A, Castilletti C, Rivelli $M R$, et al. Diagnostic performances of clinical laboratory tests using Triton X-100 to reduce the biohazard associated with routine testing of Ebola virus-infected patients. Clin Chem Lab Med. 2015;53(12):1967-73. https://doi.org/10.1515/cclm-20150119 PMID: 26053010

52. van Kampen JJA, Tintu A, Russcher H, Fraaij PLA, Reusken CBEM, Rijken M, et al. Ebola Virus Inactivation by Detergents Is Annulled in Serum. J Infect Dis. 2017;216(7):859-66. https:// doi.org/10.1093/infdis/jix401 PMID: 28961947

53. World Health Organisation (WHO). Guidance on regulations for the transport of infectious substances 2013-2014. WHO/ HSE/GCR/2012.12. Geneva: WHO; 2012. Available from: http:// apps.who.int/iris/bitstream/handle/10665/78075/WHO HSE GCR_2012.12_eng.pdf;jsessionid=FEEA1509AA9DBFD $27 \bar{F} 8 B_{1} \bar{F} 1$ EBBA 622 E1? sequence $=1$

54. United Nations (UN). Secretariat of the Convention on Biological Diversity, United Nations Environmental Programme. Nagoya Protocol on Access to genetic resources and the fair and equitable sharing of benefits arising from their utilization to the convention on biological diversity. Quebec: UN; 2011. Available from: https://www.cbd.int/abs/doc/protocol/nagoyaprotocol-en.pdf

55. Schuster I, Mertens M, Köllner B, Korytář T, Keller M, Hammerschmidt B, et al. A competitive ELISA for speciesindependent detection of Crimean-Congo hemorrhagic fever virus specific antibodies. Antiviral Res. 2016;134:1616. https://doi.org/10.1016/j.antiviral.2016.09.004 PMID: 27623345

56. Dowall SD, Richards KS, Graham VA, Chamberlain J, Hewson R. Development of an indirect ELISA method for the parallel measurement of IgG and IgM antibodies against CrimeanCongo haemorrhagic fever (CCHF) virus using recombinant nucleoprotein as antigen. J Virol Methods. 2012;179(2):335-41. https://doi.org/10.1016/j.jviromet.2011.11.020 PMID: 22155577

57. Emmerich P, Avsic-Zupanc T, Chinikar S, Saksida A, Thomé-Bolduan C, Parczany-Hartmann A, et al. Early serodiagnosis of acute human Crimean-Congo hemorrhagic fever virus infections by novel capture assays. J Clin Virol. 2010;48(4):294-5. https://doi.org/10.1016/j.jcv.2010.05.002 PMID: 20541967

58. Vanhomwegen J, Alves MJ, Zupanc TA, Bino S, Chinikar S, Karlberg H, et al. Diagnostic assays for Crimean-Congo hemorrhagic fever. Emerg Infect Dis. 2012;18(12):1958-65. https://doi.org/10.3201/eid1812.120710 PMID: 23171700

59. Zivcec M. Structure-Function Assays for Crimean-Congo Hemorrhagic Fever Virus Polymerase. Methods Mol Biol. 2018;1604:229-35. https://doi.org/10.1007/978-1-4939-69814_17 PMID: 28986838

60. European Centre for Disease Prevention and Control (ECDC). Crimean-Congo haemorrhagic fever - Annual Epidemiological Report for 2014. Stockholm: ECDC; 2016. Available from: https://ecdc.europa.eu/en/publications-data/crimean-congohaemorrhagic-fever-annual-epidemiological-report-2016-2014data

61. Ergonul O. Crimean-Congo hemorrhagic fever virus: new outbreaks, new discoveries. Curr Opin Virol. 2012;2(2):215-20. https://doi.org/10.1016/j.coviro.2012.03.001 PMID: 22482717

62. European Centre for Disease Prevention and Control (ECDC). Meeting Report. Consultation on Crimean-Congo haemorragic fever prevention and control. Stockholm: ECDC; 2009. Available from: https://ecdc.europa.eu/sites/portal/files/ media/en/publications/Publications/0809_MER_Crimean Congo_Haemorragic_Fever_Prevention_and_Control.pdf

63. European Commission. The list of diseases and their case definitions are based on the Commission Implementing Decision on the communicable diseases and related special health issues to be covered by epidemiological surveillance - Annex 1 (replacing Commission Decision No 2000/96/EC). Available from. https://ecdc.europa.eu/en/surveillance-anddisease-data/eu-case-definitions Available from. http:// ec.europa.eu/health/ph_threats/com/docs/1589_2008_en.pdf

64. European Commission. Decisions Commission Implementing Decision of 8 August 2012 amending Decision 2002/253/ EC laying down case definitions for reporting communicable diseases to the Community network under Decision No $2119 / 98 / E C$ of the European Parliament and of the Council (notified under document C(2012) 5538) (Text with EEA relevance) (2012/506/EU). Available from: http://eur-lex. europa.eu/legal-content/EN/TXT/PDF/?uri=CELEX:32012Do506 \&qid $=1428573336660$ \& from $=E N \#$ page $=38$

65. World Health Organization (WHO). An R\&D blueprint for action to prevent epidemics. Geneva: WHO; 2016. Available from: http://www.who.int/entity/blueprint/about/r_d_blueprint_ plan_of_action.pdf?ua =1

66. Leblebicioglu H, Ozaras R, Fletcher TE, Beeching NJESCMID Study Group for Infections in Travellers and Migrants (ESGITM). Crimean-Congo haemorrhagic fever in travellers: A systematic 
review. Travel Med Infect Dis. 2016;14(2):73-8o. https://doi. org/10.1016/j.tmaid.2016.03.002 PMID: 26970396

67. Fernandez-García MD, Negredo A, Papa A, Donoso-Mantke $\mathrm{O}$, Niedrig $\mathrm{M}$, Zeller $\mathrm{H}$, et al. European survey on laboratory preparedness, response and diagnostic capacity for Crimean-Congo haemorrhagic fever, 2012. Euro Surveill. 2014;19(26):20844. https://doi.org/10.2807/1560-7917. ES2014.19.26.20844 PMID: 25011064

68. Escadafal C, Olschläger S, Avšič-Županc T, Papa A, Vanhomwegen J, Wölfel R, et al. First international external quality assessment of molecular detection of Crimean-Congo hemorrhagic fever virus. PLoS Negl Trop Dis. 2012;6(6):e1706. https://doi.org/10.1371/journal.pntd.0001706 PMID: 22745842

69. Gale P, Stephenson B, Brouwer A, Martinez M, de la Torre A, Bosch J, et al. Impact of climate change on risk of incursion of Crimean-Congo haemorrhagic fever virus in livestock in Europe through migratory birds. J Appl Microbiol. 2012;112(2):24657. https://doi.org/10.1111/j.1365-2672.2011.05203.x PMID: 22118269

70. Drosten C, Göttig S, Schilling S, Asper M, Panning M, Schmitz $\mathrm{H}$, et al. Rapid detection and quantification of RNA of Ebola and Marburg viruses, Lassa virus, Crimean-Congo hemorrhagic fever virus, Rift Valley fever virus, dengue virus, and yellow fever virus by real-time reverse transcription-PCR. J Clin Microbiol. 2002;40(7):2323-30. https://doi.org/10.1128/ JCM.40.7.2323-2330.2002 PMID: 12089242

71. Deyde VM, Khristova ML, Rollin PE, Ksiazek TG, Nichol ST. Crimean-Congo hemorrhagic fever virus genomics and global diversity. J Virol. 2006;80(17):8834-42. https://doi. org/10.1128/JVI.00752-06 PMID: 16912331

72. Schwarz TF, Nsanze H, Longson M, Nitschko H, Gilch S, Shurie $\mathrm{H}$, et al. Polymerase chain reaction for diagnosis and identification of distinct variants of Crimean-Congo hemorrhagic fever virus in the United Arab Emirates. Am J Trop Med Hyg. 1996;55(2):190-6. https://doi.org/10.4269/ ajtmh.1996.55.190 PMID: 8780459

73. Midilli K, Gargili A, Ergonul O, Sengöz G, Ozturk R, Bakar $M$, et al. Imported Crimean-Congo hemorrhagic fever cases in Istanbul. BMC Infect Dis. 2007;7(1):54. https://doi. org/10.1186/1471-2334-7-54 PMID: 17553137

74. Midilli K, Gargili A, Ergonul O, Elevli M, Ergin S, Turan N, et al. The first clinical case due to AP92 like strain of Crimean-Congo Hemorrhagic Fever virus and a field survey. BMC Infect Dis. 2009;9(1):90. https://doi.org/10.1186/1471-2334-9-90 PMID: 19515251

75. Elata AT, Karsany MS, Elageb RM, Hussain MA, Eltom KH, Elbashir MI, et al. A nosocomial transmission of crimean-congo hemorrhagic fever to an attending physician in North Kordufan, Sudan. Virol J. 2011;8(1):303. https://doi.org/10.1186/1743422X-8-303 PMID: 21672268

76. Yapar M, Aydogan H, Pahsa A, Besirbellioglu BA, Bodur H, Basustaoglu AC, et al. Rapid and quantitative detection of Crimean-Congo hemorrhagic fever virus by one-step real-time reverse transcriptase-PCR. Jpn J Infect Dis. 2005;58(6):358-62. PMID: 16377867

77. Duh D, Saksida A, Petrovec M, Dedushaj I, Avsic-Zupanc T. Novel one-step real-time RT-PCR assay for rapid and specific diagnosis of Crimean-Congo hemorrhagic fever encountered in the Balkans. J Virol Methods. 2006;133(2):175-9. https://doi. org/10.1016/j.jviromet.2005.11.006 PMID: 16343650

78. Garrison AR, Alakbarova S, Kulesh DA, Shezmukhamedova D, Khodjaev S, Endy TP, et al. Development of a TaqMan minor groove binding protein assay for the detection and quantification of Crimean-Congo hemorrhagic fever virus. Am J Trop Med Hyg. 2007;77(3):514-20. https://doi.org/10.4269/ ajtmh.2007.77.514 PMID: 17827370

79. Wölfel R, Paweska JT, Petersen N, Grobbelaar AA, Leman PA, Hewson R, et al. Low-density macroarray for rapid detection and identification of Crimean-Congo hemorrhagic fever virus. J Clin Microbiol. 2009;47(4):1025-30. https://doi.org/10.1128/ JCM.01920-08 PMID: 19225100

8o. Atkinson B, Chamberlain J, Logue $\mathrm{CH}$, Cook N, Bruce C Dowall SD, et al. Development of a real-time RT-PCR assay for the detection of Crimean-Congo hemorrhagic fever virus. Vector Borne Zoonotic Dis. 2012;12(9):786-93. https://doi. org/10.1089/vbz.2011.0770 PMID: 22217175

81. Jääskeläinen AJ, Kallio-Kokko H, Ozkul A, Bodur H, Korukruoglu $G$, Mousavi M, et al. Development and evaluation of a real-time RT-qPCR for detection of Crimean-Congo hemorrhagic fever virus representing different genotypes. Vector Borne Zoonotic Dis. 2014;14(12):870-2. https://doi.org/10.1089/vbz.2014.1577 PMID: 25514124

82. Kamboj A, Pateriya AK, Mishra A, Ranaware P, Kulkarni DD, Raut AA. Novel molecular beacon probe-based real-time RTPCR assay for diagnosis of Crimean-Congo hemorrhagic fever encountered in India. BioMed Res Int. 2014;2014(496219):4 https://doi.org/10.1155/2014/496219 PMID: 24877102
83. Pang Z, Li A, Li J, Qu J, He C, Zhang S, et al. Comprehensive multiplex one-step real-time TaqMan qRT-PCR assays for detection and quantification of hemorrhagic fever viruses. PLoS One. 2014;9(4):e95635. https://doi.org/10.1371/journal. pone.0095635 PMID: 24752452

84. Schneeberger PHH, Pothier JF, Bühlmann A, Duffy B, Beuret $C$, Utzinger J, et al. Development and evaluation of a bioinformatics approach for designing molecular assays for viral detection. PLoS One. 2017;12(5):e0178195. https://doi. org/10.1371/journal.pone.0178195 PMID: 28542435

85. Osman HA, Eltom KH, Musa NO, Bilal NM, Elbashir MI, Aradaib IE. Development and evaluation of loop-mediated isothermal amplification assay for detection of Crimean Congo hemorrhagic fever virus in Sudan. J Virol Methods. 2013;190(12):4-10. https://doi.org/10.1016/j.jviromet.2013.03.004 PMID: 23542058

86. Bonney LC, Watson RJ, Afrough B, Mullojonova M, Dzhuraeva $\mathrm{V}$, Tishkova $\mathrm{F}$, et al. A recombinase polymerase amplification assay for rapid detection of Crimean-Congo Haemorrhagic fever Virus infection. PLoS Negl Trop Dis. 2017;11(10):e0006013. https://doi.org/10.1371/journal. pntd.0006013 PMID: 29028804

\section{License and copyright}

This is an open-access article distributed under the terms of the Creative Commons Attribution (CC BY 4.0) Licence. You may share and adapt the material, but must give appropriate credit to the source, provide a link to the licence, and indicate if changes were made.

This article is copyright of the authors or their affiliated institutions, 2019. 